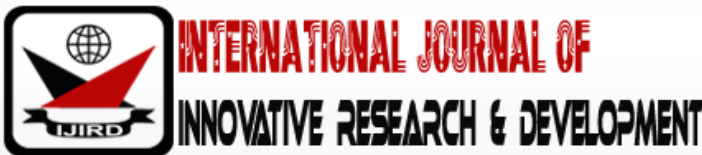

ISSN 2278 - 0211 (Online)

\section{Utilization of Web 2.0 Technologies by Lecturers of Agriculture in Tertiary Institutions in Akwa Ibom State, Nigeria}

\author{
Dr. Caroline L. Aboh \\ Associate Professor, Department of Agricultural Extension and Rural Sociology, \\ University of Calabar, Cross River State, Nigeria \\ Ini A. Akpabio \\ Professor, Department of Agricultural Economics and Extension, \\ University of Uyo, Akwa Ibom State, Nigeria \\ Collins 0. Uloh \\ Ph.D. Student, University of Uyo, Nigeria
}

\begin{abstract}
:
The study examined the extent of utilization of web 2.0 technologies by lecturers of agricultural sciences in tertiary institutions in Akwa Ibom State, Nigeria. Specifically, it identified the personal characteristics of the respondents, examined their level of awareness of web 2.0 technologies, and also ascertained respondents' purpose of utilization and extent of utilization of stated technologies. Multi-stage sampling was used in the study. Data were collected with the aid of a structured questionnaire from 100 (one hundred) lecturers. Analyses of data were done using descriptive (frequency counts, percentage and mean) statistical tools. The findings revealed that a majority of the lecturers were male and married; a higher proportion (52\%) of who possessed masters' (M.Sc.) degree. The findings showed further that the respondents were aware of, and frequently utilized many Web 2.0 tools, including Wikipedia, YouTube Drop box, LinkedIn and Twitter. These tools were however rarely utilized for educational purposes. Based on the findings of the study, it was recommended that there should be concerted effort by tertiary institutions to organize awareness campaigns and training programmes on new ICTs so as to keep lecturers abreast of, raise awareness about, and improve skills and knowledge in the utilization of these technologies for educational purposes.
\end{abstract}

Keywords: Awareness of web 2.0 technologies, utilization of web 2.0 technologies for educational purposes, lecturers of agricultural sciences

\section{Introduction}

Over the last three decades, there have been rapid growth and development in the area of information and communication technologies (ICT) (Thomas and Thomas, 2012). Particularly in the last decade, the growth in prominence of social media and Web 2.0 technologies has impacted globally on how people communicate and has had a meaningful effect on whole aspects of our lives (Okello-Obura and Ssekitto, 2015).Web 2.0 technologies provide much more flexibility in the teaching and learning processes and present lecturers and students with an innovative way of creating, distributing, searching for educational content, and sharing and re use of study contents among themselves (Majhi and Maharana, 2010). A great deal of research has thus proven its benefits in educational quality (Athanassios et al., 2013; Echeng and Usoro 2014; Nazatul, 2014; Shuaibu and Ishaq, 2014; Okello-Obura and Ssekitto, 2015).

Web 2.0, also known as social media, refers to "all web based applications which allow for creation/exchange of user generated content and enable interaction between the users." It allows people to collaborate, to get actively involved in creating content, to generate knowledge and to share information online (Grosseck, 2009). Additionally, Tyagi (2012) stated that the term 'Web 2.0 technologies' essentially covers a set of technologies comprising of interactive media that allow people to create, modify, and share information. More so, it enables communication, information sharing, collaboration, interoperability, participation, and user-centered design (Echeng and Usoro -2014).The integration of web 2.0 technologies into education has enhanced academic activities in Nigeria's tertiary institutions as it plays a pivotal role in meeting information and communication needs of institutions and individuals (Brown, 2013). It provides access to a wide range of information, such as journals, articles and papers from across the globe. It promotes a shift towards lifelong learning in higher education; when there is a great interaction between instructors, learners and relevant learning resources during the teaching 
and learning process. Instructors no longer serve solely as distributors of content, but become facilitators of learning and assessors of competency (Ruiz et al, 2006). Web 2.0 is known by various names which fundamentally emerged as a result of its characteristics and some of them include "participatory media" (Bull et al., 2008), "social digital technologies" (Palfrey and Gasser, 2008) and "second wave of the World Wide Web" (Azab, Abdelsalam and Gamal, 2013). Web 2.0 comprises a number of technologies that can support teaching and learning activities, such as Blogs, Micro-blogs, Wikis, Real Simple Syndication (RSS) Feeds, YouTube, Flicker, Facebook, Twitter, Skype, Podcasts, Google Apps and WhatsApp, (Armstrong and Franklin, 2008; Al-Qirim, 2010; Harinarayana and Raju, 2010; Luo, 2010; Makori, 2011; Hough and Neuland, 2012). Since their emergence about a decade ago, Web 2.0 technologies have been overwhelmingly adopted by various fields such as agriculture, engineering, mining, military, media and telecommunications, music and education. In essence, higher education has not been spared from the web 2.0 lure. Smart phones, computers, laptops and other ICT gadgets, which are utilized to connect to the internet, are now affordable and prevalent among lecturers in Nigeria's tertiary institutions. Such developments have prompted the researcher to underscore the need to re-examine the role of the Web 2.0 technologies in teaching and learning in tertiary institutions in Akwa Ibom state, Nigeria.

In Nigeria, Akwa Ibom State is home to the Ibom E-Library, a world- class information centre. The utilisation of the internet is prevalent among educational institutions as well as business and other organizations. With the government effort to build a digital society in Akwa Ibom State, Web 2.0 technologies will play important roles in adding more sophisticated information and communication technologies with the properties of creating information on the one hand, and facilitate sharing, interaction, and collaboration on the other hand (Burhanna, Seeholzer, and Salem, 2009).A great deal of research has thus proven its benefits in educational quality (Athanassios et al., 2013; Echeng and Usoro 2014; Nazatul, 2014; Shuaibu and Ishaq, 2014; Okello-Obura and Ssekitto, 2015).

A number of studies (Kadzera, 2006; Greenhow, Robelia and Hughes, 2009; Nyirongo, 2009; Zinn, 2009) have thus concluded that the adoption of the emerging internet technologies can enhance teaching and learning. Most of the studies that were previously conducted in the area of internet utilization in Nigeria focused on the traditional applications of the first generation of the World Wide Web, such as e-mail and search engines (Gbola, 2013). All of the studies concluded that there is an increase in the number of people who utilise the Internet, but does that reflect the scope and diversity of the technologies and services that are provided by the World Wide Web within the Internet? (Kumar and Kaur, 2005; Sadanand and Shamprasad, 2008; Aduwa-Ogiegbean and Uwameiye 2009; Bynum, 2011).

This study is an attempt to provide a response to some parts of the above-stated question. In essence, the problem this study tends to address is to bring to the fore, the current status of web 2.0 technologies utilization by lecturers of agriculture for educational purposes. It is against this background that this study seeks toexamine the extent ofutilization of web 2.0 technologies by lecturers of agriculture in tertiary institutions in Akwa Ibom State, Niger Delta, Nigeria. Specifically, the study analysed the personal characteristics of lecturers of agriculture in the study area, identified the level of awareness of web 2.0 technologies by this set of respondents, ascertained the purpose of utilization of stated technologies and determined the extent of utilization of web 2.0 technologies by these respondents.

\section{Methodology}

The study was conducted in Akwa Ibom State, which was created on September 23rd, 1987 and has Uyo as its capital. The State is one of the Niger Delta States, located in the South-South geopolitical and South East ecological zones of Nigeria. The State is situated between latitude $4^{0} 31^{\prime}$ and $5^{0} 31^{\prime}$ North and longitudes $7^{0} 35^{\prime}$ and $8^{0} 25^{\prime}$ East with an estimated total area of $7,245,935 \mathrm{~km}^{2}$, and has a shoreline of $129 \mathrm{~km}$ on the Atlantic Ocean to the South. It shares borders with Cross River State to the East, Abia State to the north and Rivers State to the West (Ajana, 1996 and Uwatt, 2000). The 2006 census put the State's population at 3,920,208, out of which $2.044,510$ are male while 1,875,698 are females. The major ethnic groupings in the state are the Ibibio, Annang and Oron. Ibibio language is the main language, but there are variations in dialects within the state.

Notable tertiary educational institutions in the state include: the University of Uyo; Maritime Academy of Nigeria; Akwa Ibom State University and Obong University. Others include; Akwa Ibom State Polytechnic, Uyo City Polytechnic, Apex Polytechnic, Heritage Polytechnic, Schools of Nursing (Uyo, Eket, Oron, Ikot Ekpene, Etinan), Akwa Ibom State College of Education and College of Arts and Science, Nung Ukim.

The study population included all lecturers of agriculturein tertiary institutions located in Akwa Ibom State.A multi-stage sampling procedure was used to select the sample for the study.In the first stage,four out of the twelve (12) tertiary institutions in Akwalbom State were purposively selected to ensure that only tertiary institutions that offered agricultural courses and have lecturers of agriculturewere selected for the study. The selected tertiary institutions were University of Uyo (UNIUYO), Akwa IbomState University (AKSU), Akwa Ibom State College of Arts and Science (AKSCAS) and Akwa Ibom State College of Education (AKSCOE). In the second stage, out of a population of 238 lecturers, $42 \%$ of lecturers were randomly selected resulting in a total sample size of 100 lecturers that participated in the study.Data were collected with the aid of a structured questionnaire and analyzed using descriptive statistics such as frequency, means and Percentages. 


\section{Results and Discussion}

\subsection{Personal Characteristics of Lecturers of Agriculture in the Study Area}

Table 1 shows that the highest proportion of respondents, 54\% was sampled from the University of Uyo (UNIUYO), while the lowest proportion of respondents, $8 \%$ were from the Akwa Ibom State College of Art and Science (AKCAS). Implications are that there were more lecturers in the faculty of Agriculture in University of Uyo than any other school sampled for the study.

Table 1 also depictss that about $70 \%$ of the lecturers were male, while $30 \%$ were female. It may be deduced that less number of female lecturers take up teaching appointments in higher institutions. Findings further reveal that the highest proportion of respondents (38\%) was between the age bracket of 36 and 45 years, while the lowest proportion of respondents (4\%)was between 55 years and above. This implies that most of the respondents are still in their active ages and hence might be better physically positioned to perform the duty of imparting knowledge to their students more effectively.The table also shows that about 78\%were married, while $6 \%$ were either divorced or widowed. In essence, majority of the respondents were married and may be considered to be responsible and matured enough to give reasonable answers to research questions.

Table 1 details the fact that about $18 \%$ of the lecturers were of the Department of Agricultural Economics and Extension, while 14\% were of the Department of Animal Science. Indications are that these two departments had more lecturers than other departments. It was also revealed (Table 1) that about 52\% of the respondents possessed Master of Science (M.Sc.) degrees, $42 \%$ possessed $\mathrm{PhD}$ (doctorate) degrees, while the remaining 6\% respondents possessed Bachelor's (B.Sc.) degrees. Indications are that, in terms of academic attainment, respondents were relatively active, with great potential for productivity and growth on the job. Also, according to Table 1, the highest proportion of respondents (30\%) had attained the rank of Assistant Lecturer, while the lowest proportion of respondents(2\%) had attained the rank of Professor. The implication for the teaching profession here is that there is room for growth and development.With regard to length of service,Table 1 shows that the highest proportion of respondents (60\%) had between 1 - 10 years work experience, while the lowest proportion of respondents, $(2 \%)$ had between 30 years and above work of experience. The implication of these findings on the utilization of web 2.0 technologies is that the respondents are possibly young and growing on the job and may be more zealous in utilizing web 2.0 technologies for teaching and research in order to be promoted in their careers. These findings are in tandem with the findings of Azab, Abdelsalam and Gamal (2013) who discovered, while investigating the utilization of Web 2.0 technologies by academic staff in public universities, that lecturers with less than five years of work experience utilized web 2.0 technologies more than other respondents with more experience. Possible reasons for this action may be that most of such lecturers are young and new on the job and are thus looking for ways to get information for their academic papers, which are critical to their various promotions as well as utilizing web 2.0 technologies for their lectures. With reference to monthly

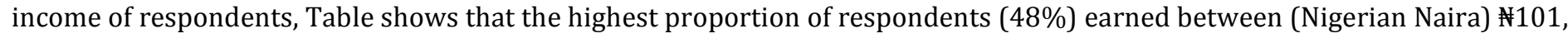
000 and $\$ 200,000$ per month, while the lowest proportion of respondents $(2.1 \%)$ earned more than $\$ 500,000$ per month. With more financial resources at their disposal, lecturers are expected to acquire smart phones, computers, laptops and other ICT gadgets, which are used to connect to the internet.

\begin{tabular}{|c|c|c|}
\hline Variables & Frequency & Percent \\
\hline Institution of Affiliation & & 100 \\
\hline UNIUYO & 54 & 30 \\
\hline AKSU & 30 & 8 \\
\hline AKCOE & 8 & 8 \\
\hline AKCAS & 8 & 70 \\
\hline Sex & 70 & 30 \\
\hline Male & 30 & 28 \\
\hline Female & & 38 \\
\hline Age (years & 28 & 30 \\
\hline $25-35$ & 38 & 4 \\
\hline $36-45$ & 30 & 16 \\
\hline $46-55$ & 4 & 78 \\
\hline Above 55 & & 6 \\
\hline Marital status & 16 & 18 \\
\hline Single & 78 & 8 \\
\hline Married & 6 & 8 \\
\hline Divorced & 18 & 14 \\
\hline Department of affiliation & 8 & \\
\hline Agricultural economics and extension & 8 & \\
\hline Agricultural education & 8 & \\
\hline Animal sciencelogy & & \\
\hline
\end{tabular}




\begin{tabular}{|c|c|c|}
\hline Variables & Frequency & Percent \\
\hline Crop science & 8 & 8 \\
\hline Fishery and aquaculture & 10 & 10 \\
\hline Forestry and wildlife & 10 & 10 \\
\hline Food science and technology & 10 & 10 \\
\hline Soil science & 8 & 8 \\
\hline Home economics & 6 & 6 \\
\hline \multicolumn{3}{|l|}{ Academic attainment } \\
\hline B.Sc & 6 & 6 \\
\hline M.Sc & 52 & 52 \\
\hline Ph.D & 42 & 42 \\
\hline \multicolumn{3}{|l|}{ Rank } \\
\hline Graduate assistant & 6 & 6 \\
\hline Assistant lecturer & 30 & 30 \\
\hline Lecturer II & 28 & 28 \\
\hline Senior lecturer & 10 & 10 \\
\hline Associate professor & 4 & 4 \\
\hline Professor & 2 & 2 \\
\hline \multicolumn{3}{|l|}{ Year of working experience } \\
\hline $1-10$ & 60 & 60 \\
\hline $11-20$ & 26 & 26 \\
\hline $21-30$ & 12 & 12 \\
\hline Above 30 & 2 & 2 \\
\hline \multicolumn{3}{|l|}{ Salary ( } \\
\hline $10000-100000$ & 16 & 16 \\
\hline $101000-200000$ & 48 & 48 \\
\hline $201000-300000$ & 26 & 26 \\
\hline $301000-400000$ & 8 & 8 \\
\hline $401000-500000$ & 2 & 2 \\
\hline
\end{tabular}

Table 1: Personal Characteristics of Lecturers of Agriculture in the Study Area ( $N=100)$

Source: Field Data Survey, 2017

\subsection{Awareness of Web 2.0 Technologies Bylecturers of Agriculture in the Study Area}

Table 2 shows that all lecturers were aware of Facebook (100\%), Twitter (100\%) and LinkedIn (100\%), whereas only $42 \%$ (21) or fewer were aware of Viber, Picasa and Delicious.

These findings are in line with that of Ping and Issa (2011) who conducted a study to investigate the awareness and knowledge of Web 2.0 technologies among undergraduate lecturers and tutors at the Curtin Business Information Systems in Australia. The findings show further that all lecturers were aware of LinkedIn. Most professionals including lecturers have accounts with LinkedIn where they display their resume to remain visible so that potential employers can see their accomplishments, experiences and skill sets. After all, LinkedIn (2014) claims that it is "the world's largest professional network" boasting of "400 million members in over 300 countries and territories around the world. This corroborates with the report of Ajjan and Hartshorne (2008) who also found that a good number of lecturers were aware of Blogs, RSS Feeds and most social networks.

The proliferation of smart phones in Nigeria has contributed significantly to lecturers' awareness of the afore-stated technologies because most phones, especially smart phones have these technologies either pre-installed or can be installed as per users-wish. 


\begin{tabular}{|c|c|c|}
\hline Purposes of Web 2.0 Technologies & Frequency & Percent \\
\hline Facebook & 100 & 100 \\
\hline Twitter & 100 & 100 \\
\hline Whatsapp & 100 & 100 \\
\hline Wikipedia & 100 & 96 \\
\hline Linkedln & 100 & 92 \\
\hline Skye & 96 & 88 \\
\hline Google app & 92 & 86 \\
\hline YouTube & 88 & 86 \\
\hline Blog & 86 & 68 \\
\hline Dropbox & 86 & 66 \\
\hline Flickr & 68 & 64 \\
\hline Rss feeds & 66 & 42 \\
\hline Podcast & 64 & \\
\hline Viber & 42 & \\
\hline Picasa & 42 & \\
\hline Delicious & 36 & 36 \\
\hline
\end{tabular}

Table 2: Distribution of Lecturers of Agriculture Based on Awareness of Web 2.0 Technologies $(N=100)$ Source: Field Data Survey, 2017

\subsection{Purpose of Utilization of Web 2.0 Technologies by Lecturers of Agriculture}

Table 3 shows that lecturers utilized Web 2.0 technologies to publish research papers (100\%), to search for information (98\%) and to communicate classroom and research activities (92\%), whereas only $45 \%$ or fewer lecturers utilize web 2.0 technologies to enhance concept explanation (45\%), to store lecture notes (43\%) and to schedule activities (40\%).

The result also corroborates with the findings of Azab, Abdelsalam and Gamal (2013) who in their study, investigated the utilization of Web 2.0 technologies by academic staff in public universities and findings show that a high number of lecturers utilize Web 2.0 technologies such as Blogs, Wikis and social networks for collaboration in research activities and sharing academic content. Along the same lines, Luo (2010) argues that Web 2.0 technologies can be utilized to develop research projects and provide a reflection from the prescribed readings and that the academic staff can utilize Blogs, Wikis, Facebook, Twitter, Delicious and Podcasts to publish course resources for distance education students, facilitate group authoring of a document, facilitate course evaluation and allow students to collaboratively write reviews of courses they have taken.

\begin{tabular}{|c|c|c|}
\hline Purposes of Web 2.0 Technologies & Frequency & Percent \\
\hline To publish research papers & 100 & 98 \\
\hline To search for information & 98 & 92 \\
\hline To communicate in classroom & 92 & 90 \\
\hline To communicate with colleagues & 90 & 84 \\
\hline To keep-to-date on topic of interest & 84 & 68 \\
\hline For collaboration in research activities and \\
sharing & 80 & 66 \\
\hline For social activities & & 66 \\
\hline Handing assignments to students & 68 & 50 \\
\hline Receiving feedback from students & 66 & 48 \\
\hline E-learning & 66 & \\
\hline Preparing lecture notes & 50 & \\
\hline Uploading lecture notes & 48 & \\
\hline Storing of lecture notes & 48 & \\
\hline Scheduling of activities & 46 & \\
\hline Table 3: Distribution of & 44 & \\
\hline
\end{tabular}

Table 3: Distribution of Lecturers of Agriculture Based on Purpose of Utilization of Web 2.0

Technologies $(N=100)$

Source: Field Data Survey, 2017

\subsection{Extent of Utilization of Web 2.0 Technologies for Educational Purposes by Lecturers of Agriculture in the Study Area}

Table 4 shows that lecturers frequently utilized Wikipedia $(\bar{X}=2.56)$, YouTube $(\bar{X}=2.36)$ and Twitter $(\bar{X}=2.28)$ for educational purposes, while lecturers seldom utilized Skype $(\bar{X}=1.22)$, Flickr $(\bar{X}=1.16)$ and Viber $(\bar{X}=1.10)$. The respondents had a pooled mean rating of 1.77 in their response to the questions ascertaining their level of utilization of web 2.0 technologies for educational purposes. This pooled mean score was below the midpoint score of 2.0. This implies that the level of utilization of web 2.0 technologies for educational purposes by lecturers of agriculture in the study area was low. A 
summation of respondents' extent of utilization of Web 2.0 technologies for educational purposes (Table 5) also revealed that only 26 percent of respondents frequently utilized these tools for academic purposes, as against a far larger (74\%) proportion that 'seldom utilized' those tools for academic purposes. Implications are that Web 2.0 technologies are still in a rudimentary stage,in terms of its utilization for educational purposes in the study area. This may be ascribed to a range of factors whichEcheng and Usoro (2014) depicted as principally technical, personal, economical and time related; in nature.

The findings show that despite lecturers' relatively high level of awareness of web 2.0 technologies(table 2) these tools are rarely generally utilized for educational purposes. Implications are that agricultural lecturers' awareness of Web 2.0 technologies do not necessarily translate into actual utilization of these technologies in their academic work. In tandem with these findings, Kumar (2009) cautioned that, the popularity of some Web 2.0 technologies among lecturers do not necessarily mean that these are being utilized for educational purposes.

\begin{tabular}{|c|c|c|c|c|c|c|c|c|c|}
\hline $\begin{array}{c}\text { Web 2.0 } \\
\text { Technology }\end{array}$ & \multicolumn{2}{|c|}{$\begin{array}{c}\text { Never } \\
\text { Utilized }\end{array}$} & \multicolumn{2}{c|}{$\begin{array}{c}\text { Seldom } \\
\text { Utilized }\end{array}$} & \multicolumn{2}{|c|}{} & Total & $\begin{array}{c}\text { Mean } \\
\bar{X}\end{array}$ & Decision \\
\hline & $\mathrm{F}$ & $\%$ & $\mathrm{~F}$ & $\%$ & $\mathrm{~F}$ & $\%$ & & & \\
\hline Wikipedia & 20 & 20 & 4 & 4 & 76 & 76 & 256 & 2.56 & Frequently Utilized \\
\hline Google Apps & 38 & 38 & 2 & 2 & 60 & 60 & 222 & 2.22 & Frequently Utilized \\
\hline You Tube & 30 & 30 & 4 & 4 & 66 & 66 & 236 & 2.36 & Frequently Utilized \\
\hline Blog & 34 & 34 & 6 & 6 & 60 & 60 & 226 & 2.26 & Frequently Utilized \\
\hline Twitter & 32 & 32 & 8 & 8 & 60 & 60 & 228 & 2.28 & Frequently Utilized \\
\hline Podcast & 58 & 58 & 6 & 6 & 36 & 36 & 178 & 1.78 & Seldom Utilized \\
\hline Dropbox & 32 & 32 & 14 & 14 & 54 & 54 & 222 & 2.22 & Frequently Utilized \\
\hline Facebook & 72 & 72 & 10 & 10 & 18 & 18 & 146 & 1.46 & Seldom Utilized \\
\hline LinkedIn & 34 & 34 & 14 & 14 & 52 & 52 & 218 & 2.18 & Frequently Utilized \\
\hline RSS Feeds & 78 & 78 & 6 & 6 & 16 & 16 & 138 & 1.38 & Seldom Utilized \\
\hline WhatsApp & 74 & 74 & 10 & 10 & 16 & 16 & 142 & 1.42 & Seldom Utilized \\
\hline Delicious & 74 & 74 & 14 & 14 & 12 & 12 & 138 & 1.38 & Seldom Utilized \\
\hline Skype & 84 & 84 & 10 & 10 & 6 & 6 & 122 & 1.22 & Seldom Utilized \\
\hline Flickr & 90 & 90 & 4 & 4 & 6 & 6 & 116 & 1.16 & Seldom Utilized \\
\hline Picasa & 78 & 78 & 16 & 16 & 6 & 6 & 128 & 1.28 & Seldom Utilized \\
\hline Viber & 92 & 92 & 6 & 6 & 2 & 2 & 110 & 1.10 & Seldom Utilized \\
\hline
\end{tabular}

Table 4: Distribution of Lecturers Based on Extent of Utilization of Web 2.0 Technologies for

Educational Purposes $(N=100)$

Mid-Point $=2.0$, Pooled Mean $=1.77, F=$ Frequency, $P=$ Percentage

Decision: Any Mean Score $<2.0=$ Seldom Utilized

Any Mean Score $>2.0=$ Frequently Utilized

\begin{tabular}{|c|c|c|c|}
\hline $\begin{array}{c}\text { Range of } \\
\text { Utilization Scores }\end{array}$ & $\begin{array}{c}\text { Extent of } \\
\text { Utilization }\end{array}$ & Frequency & Percentage \\
\hline $16-32$ & Seldom Utilized & 74 & 74 \\
\hline $33-48$ & Frequently Utilized & 26 & 26 \\
\hline
\end{tabular}

Table 5: A Summary Table on the Extent of

Utilization of Web 2.0 Technologies among

Lecturers of Agriculture $(N=100)$

\section{Conclusion and Recommendations}

The study examined the level of utilization of web 2.0 technologies by lecturers of agriculture in tertiary institutions in Akwa Ibom State, Nigeria.Majority of the lecturers of agriculture in the study area are aware of Web 2.0 technologies which could be utilized for educational purposes due to the proliferation of mobile phones which support most of these technologies. Regardless of the extentof awareness of web 2.0 technologies for educational purposes, indications however are that these tools are rarely utilizedfor the various educational purposes for which the respondents are involved in. Based on the findings of the study the following recommendations were made:

- Although lecturers have adopted some Web 2.0 technologies, it has been revealed that a good number of technologies that could be equally utilized for educational purposes are yet to be adopted. This is mainly because some Web 2.0 technologies are not popular in Nigeria in general and in Akwa Ibom State in particular, in addition to the fact that new Web 2.0 technologies continue to emerge on regular basis. Therefore there should be a concerted effort by tertiary institutions to organize awareness campaigns and training programmes on new ICTs so as to keep lecturers abreast of, raise awareness about, and improve skills and knowledge in the utilization of web 2.0 technologies for educational purposes.

- The management of tertiary institutions and relevant agencies should intensify efforts in the provision of ICT facilities and improvement of power supply in tertiary institutions of higher learning in Akwa Ibom State. 


\section{References}

i. Aduwa-Ogiegbean, S. E. and Uwameiye, R. (2009). Internet Usage among University Lecturers in southern Nigeria. Library Philosophy and Practice 2 (1): 1

ii. Ajjan, H. and Hartshorne, R. (2008). Investigating Faculty Decisions to Adopt Web 2.0 Technologies: Theory and Empirical Tests. Internet and Higher Education, 11(2):71-80.

iii. Al-Qirim, N. (2010). Critical Success Factors for Pedagogy 2.0. [Online]. Available at http://www.iiis.org/CDs2011/CD2011SCI/S2ES2011/PapersPdf/SB294GV.pdf [20 July 2017].

iv. Armstrong, J. and Franklin, T. (2008). A Review of Current and Developing International Practice in the Web 2.0 in Higher Education. [Online]. Available at: http://goo.gl/gR8mRh[10 June 2017].

v. Athanassios, J., Panagiotis, T., Dimitrios, R. and Anastasia, S. (2013). Preparing Teachers to Integrate Web 2.0 in School Practice: Toward a Framework for Pedagogy 2.0. Department of Social and Educational Policy, University of Peloponnese, Greece Australasian Journal of Educational Technology, 2013, 29(2).

vi. Armstrong, J. and Franklin, T. (2008). A Review of Current and Developing International Practice in the Web 2.0 in Higher Education. [Online]. Available at: http://goo.gl/gR8mRh[10 June 2017].

vii. Azab, A. N., Abdelsalam, M. H. and Gamal, S. (2013). Use of Web 2.0 Collaboration Technologies in Egyptian Public Universities: An Exploratory Study. [Online]. Available at: http://goo.gl/z6w70j [20 August 2015].

viii. Brown, S. A. (2012). Seeing Web 2.0 in Context: A Study of Academic Perceptions. Internet and Higher Education, 15(1):50-57.

ix. Bull, G., Thompson, A., Searson, M., Garofalo, J., Park, J., Young, C. and Lee, J. (2008). Connecting Informal and Formal Learning Experiences in the Age of Participatory Media. Contemporary Issues in Technology and Teacher Education, 8(2):100-107.

x. Burhanna, K., Seeholzer, J. and Salem, Jr., J. (2009). No Natives Here: A Focus Group Study of Students Perceptions of Web 2.0 and the Academic Library. The Journal of Academic Librarianship, 35(6), 523-532.

xi. Bynum, S. L. (2011). Utilizing Social Media to Increase Student Engagement: A Study of Kern County Public Schools (Masters Dissertation, California State University, 2011)

xii. Echeng, R. and Usoro, A. (2014). Factors of Acceptance and Use of Web 2.0 Technologies for Effective Implementation in Higher Education: Present Level of Use in Two Countries. Proceedings on ICICTE. University of the West of Scotland United Kingdom.

xiii. Greenhow, C., Robelia, B. and Hughes, J. E. (2009). Learning, Teaching and Scholarship in a Digital Age Web 2.0 and Classroom Research: What Path should We Take Now? Educational Researcher, 38(4):246-259.

xiv. Grosseck, G. (2009). To Use or not to Use Web 2.0 in Higher Education? Procedia Social and Behavioural Sciences, 1(2):478-482.

xv. Harinarayana, N. and Raju, V. (2010). Web 2.0 Features in University Library Web Sites. The Electronic Library, 28(3):69-88.

xvi. Hough, J. and Neuland, E. (2012). Comparison of Web 2.0 On-Line Usage by on Campus and Distance Learning Students. [Online]. Available at: http://goo.gl/hBFdrz [25 May 2017].

xvii. Kumar, R. and Kaur, A. (2005) Internet and Its Use in the Engineering Colleges of Punjab, India: A CaseStudy. Webology 2, (44).

xviii. Kadzera, C. M. (2006). Use of Instructional Technologies in Teacher Training Colleges in Malawi. Virginia: Virginia Polytechnic Institute and State University, PhD Thesis.

xix. Luo, L. (2010). Web 2.0 Integration in Information Literacy Instruction: An Overview. Journal of Academic Librarianship, $36(10): 32-40$.

xx. Makori, E. O. (2011). Bridging the Information Gap with the Patrons in University Libraries in Africa: The Case for Investments in Web 2.0 Systems. Library Review, 61(4):30-40.

xxi. Majhi, S. and Maharana, B. (2011). Familiarity of Web 2.0 and its Application in Learning: A Case Study of Two Indian Universities. Journal of Library and Information Science, 3(6):120-129.

xxii. Nazatul A. (2014). Integration of Web 2.0 Tools in Learning a Programming Course. The Turkish Online Journal of Educational Technolog, 13(1): 25-38.

xxiii. Nyirongo, K. N. (2009). Technology Adoption and Integration: A Descriptive Study of a Higher Education Institution in a Developing Nation. Virginia: Virginia Polytechnic Institute and State University, PhD Thesis.

xxiv. Okello-Obura, C. and Ssekitto, F. (2015). Web 2.0 Technologies Application In Teaching And Learning By Makerere University Academic Staff. Library Philosophy and Practice (e journal).Paper1248. http://digitalcommons.unl.edu/libphilprac/1248

xxv. Palfrey, J. and Gasser, U. (2008). Born Digital: Understanding the First Generation of Digital Natives. New York: Basic Books.

xxvi. Ping, C. S. and Issa, T. (2011). The Awareness and Knowledge of Web 2.0 Technologies in Education: An Australian Perspective. The International Journal of Learning, 18 (2):1-17.

xxvii. Ruiz, J. G., Mintzer, M. J. and Leipzig, R. M., (2006). "The impact of e-learning in medical education”, Academic medicine, Vol. 81 No. 3.

xxviii. Sadanand, Y. B. and Shamprasad M. P. (2008). Use of Internet by Research Scholars at Shivaji University, Kolhapur. Annals of Library and Information Studies. 55(1): 123-126.

xxix. Shuaibu, U. and Ishaq, O. (2014). Encouraging Knowledge Sharing Using Web 2.0 Technologies in Higher Education: A Survey. International Journal of Managing Information Technology 6(1): 514-689

xxx. Thomas, M. and Thomas, H. (2012). Using new social media and Web 2.0 technologies in business school teaching and learning. Journal of Management Development. Vol. 31(4),

xxxi. Tyagi, S. (2012). Adoption of Web 2.0 Technology in Higher Education: A Case Study of Universities in National Capital Region, India. International Journal of Education and Development Using Information and Communication Technology, 8(2):28-43.358 367

xxxii. Zinn, S. (2009). Readiness to Adopt E-Learning: Pioneering a Course in School Librarianship Education. South African Journal of Libraries and Information Science, 75(2):159-169. 
